\title{
Allomorphy and the Autonomy of Morphology
}

\author{
Geert Booij
}

\begin{abstract}
This paper discusses the question to what extent morphology is an autonomous module of the grammar. After a general survey and discussion of the issues involved, a detailed analysis is given of allomorphy phenomena. It is argued that these phenomena support the relative autonomy of morphology since the formal regularities involved cannot be deduced from phonological or syntactic principles. In addition, a proper account of these formal regularities requires reference to the form of paradigmatically related words. That is, paradigmatic relations play a crucial role, which is another characteristic property of the morphological module.
\end{abstract}

\section{Introduction: Morphology as an Autonomous Module}

The position of morphology in the grammar has been a persistent topic of debate in generative grammar. ${ }^{1}$ The basic question is to what extent morphology is to be seen as a separate component or module of the grammar, and - related to this question - to what extent it is governed by principles of its own that distinguish it from syntax on the one hand, and phonology on the other. For instance, we might assume that the order of morphemes in a morphologically complex word can be accounted for by independently motivated syntactic principles, and that the allomorphy of morphemes within complex words follows from independently motivated phonological rules. Thus, given such a radical move, there is nothing left for a separate morphological module of the grammar.

Before presenting, in this introductory section, a short survey of the different answers given to this question of the degree of autonomy of morphology, I would like to stress the difference between the notions 'component' and 'module', since this is very relevant here. If morphology is a separate module rather than a component, this means that morphology does not represent a particular stage in the derivation of well-formed sentences, but that there is a specific set of morphological principles that apply whenever they are relevant for a particular configuration of morphemes. In this latter interpretation it may still be the case that mor-

Folia Linguistica $X X X I / 1-2$

0165-4004/97/31-25 \$2.-

(C) Mouton de Gruyter, Berlin Societas Linguistica Europaea 
phological and syntactic structure are interspersed. Such a position is defended in, for instance, Borer's $(1988,1991)$ so-called Parallel Morphology.

A straightforward argument for the modular interpretation of morphology is that in Dutch compounds phrases may form the non-head constituent, as in $\left[[\text { kleine-kinderen }]_{\mathrm{NP}} \mathrm{gedrag}\right]_{\mathrm{N}}$ 'small children's behavior': the well-formedness of the whole expression is determined by morphology, in particular by the rule of Dutch that nominal compounds may consist of a nominal head preceded by a phrase, whereas the well-formedness of the constituent kleine kinderen, being a NP, is determined by syntax. In other words, the autonomy of morphology does not necessarily mean that morphology is separated completely from syntax, and that syntax cannot feed morphology. What is at stake is whether the properties of morphological constructs can be accounted for completely by syntax and phonology.

The inclination to ignore the issue of the demarcation of morphology with respect to syntax is an understandable one if morphology is conceived as morpheme syntax, i.e. as a set of principles or rules for concatenating morphemes into words. This is the syntagmatic approach to morphology which has so far been the dominant approach in American linguistics, both pre-generative and generative. This predominance of the syntagmatic approach to morphology certainly has to do with the historical background of American linguistics, whose origin lies in the study of Amerindian languages. These languages exhibit rich morphological systems, and distinguishing words from phrases is no easy task as far as these languages are concerned. On the other hand, in the tradition of European linguistics the distinction between morphology and syntax was usually taken for granted given the rich paradigmatic systems and the pervasiveness of non-phonological allomorphy in the morphology of Indo-European languages.

Within the syntagmatic approach to morphology one approach has been quite dominant since the transformationalist theory of word formation was given up after Chomsky (1970). It is the hypothesis that morphology is located in a separate component of the grammar, and that the structure of complex words is determined by rules that are similar to the rules of phrase structure in syntax. That is, morphological structures are organized like syntactic structures, as trees. Notions such as 'head' not only play a role in syntax, but also in accounting for the morphological structure of words. Characteristic examples of this approach are Lieber (1980), Williams (1981), Selkirk (1982) (with the revealing title The Syntax of Words), Toman (1983), and Di Sciullo \& Williams (1987). This approach does not necessarily exclude that morphology has its own categories as well (e.g. that of 'root' and 'words' as in Selkirk 1982, and categories below zero 
such as $\mathrm{X}^{-1}$ ), but the representation of morphological structure is like that of phrases.

Although these approaches make use of structural analogies with syntax in accounting for the internal structure of complex words, morphology and syntax are nevertheless separated, i.e. they defend a lexicalist view of morphology. The lexicalist position chosen in these approaches manifests itself in two ways: (1) the internal structure of words is not visible to syntax (the principle of Lexical Integrity), and (2) there are specific categories and principles for the syntax of morphemes below the word level.

As Borer (1991:121-122) rightly points out, in these approaches the differences between morphology and syntax remain. Notions such as 'maximal projection' and 'head' receive different interpretations in syntax and morphology. For instance, the notion 'head' is defined differently: in morphology it is defined in terms of position (e.g. the head is in the right hand position in English), whereas in syntax the head of a constituent is defined structurally, not in terms of the position of a constituent in the relevant configuration.

A reductionist variant of this approach, which can be referred to as the 'syntax below zero' approach, is the model in which syntax and morphology are not located in different components, and syntax is not denied access to the internal 'syntactic' structure of words, at least not in principle. This radical variant of the word syntax approach can be found in Lieber (1992) and Ackema $(1995)^{2}$. In this approach the only essential difference between syntactic structure and word structure is that the $\mathrm{X}^{\circ}$ level is the minimal level for syntactic constituents, but the maximal level for morphological constituents. Ackema's position is that "morphology is not done in syntax, but is governed by the same principles as syntax" (Ackema 1995:1), and he also states that "it is unneccessary to assume that there is an autonomous module of grammar dealing exclusively with morphology" (Ackema 1995:2). There is no Principle of Lexical Integrity, and lexical integrity, in so far as it is a correct empirical generalization, is seen as the effect of other principles of the grammar.

As is clear from the above, there is no necessary connection between the lexicalist position and the word syntax approach. This can also be seen from the fact that one can also take the lexicalist position without accepting the word syntax approach. Lexicalists may also assume, with Aronoff (1976), that morphology is characterized in terms of a set of word formation rules that expand the lexicon. In this approach, morphology is different from syntax in that it consists of a component of rules sui generis, word formation rules, that either combine two lexemes (compounding) or add an affix to a lexeme (derivation). Thus, word 
formation is not the concatenation of morphemes, as in Halle (1973), the first paper on lexicalist morphology, but a set of operations on lexemes.

The problem with the reductionist program as defended in Lieber (1992) and Ackema (1995) is pointed out very clearly in Spencer (1993), a review of Lieber (1992): "Morphologists should establish domain-specific principles and determine on the basis of these how morphology interfaces with other grammatical components. After all, if we don't look for specifically morphological principles and they happen to be there, we'll never find them" (Spencer 1993:586).

This is precisely the position that I will take in this paper: the starting point is that morphology is not reducible to phonology and/or syntax, a view that is also advocated in Anderson (1992) and Aronoff (1994), and I will discuss a set of phenomena that are typically morphological in nature: the distributional patterns of allomorphs.

Before doing so in the next section, let me point out that we can already see that syntax differs from morphology if we look at how each of them interacts with phonology. As pointed out by Pullum \& Zwicky (1988), syntax is basically phonology-free. There is, for instance, no rule of syntax that is sensitive to phonological properties of its constituents. We would be quite surprised to find a syntactic movement rule that preposes NP's with an initial obstruent only: "the extent of truly phonological influence on truly syntactic rules is zero" (Pullum \& Zwicky 1988:272). Morphology, on the contrary, clearly interacts with phonology. In prosodic morphology, for instance, the content of the morphological operations is determined by prosodic properties of the stem to which they apply. Also, the choice of a particular affix from a set of competing ones is often determined by the phonological properties of the stem to which they attach (cf. below). Whether a bound morpheme is prefixed or infixed may depend on what the phonologically most optimal form will be (McCarthy \& Prince 1993). Even the difference between prefix status or suffix status of a bound morpheme may have to do with phonology: Noyer (1993) pointed out that in Huave there are bound morphemes that are either prefixed or suffixed, depending on which of the two options results in the optimal phonological output. So it appears that in terms of interface morphology is clearly different from syntax.

The position that there are syntactic rules that create morphological structure (a position that obviously reduces the differences between syntax and morphology) has been taken by Baker (1988) who argued that - at least certain types of - word formation should be accounted for by means of syntactic movement rules, of the Head-to-Head movement type. Such rules can account for noun incorporation, the formation of causative verbs, etc. These movement rules not only create the relevant types of complex word, but also account for the effects of 
morphology on the valency of these complex words. For instance, noun incorporation turns a transitive verb into an intransitive one, which follows from the movement of the underlying object-NP to the verbal head of the VP. Similar proposals have been made in Hoekstra et al. (1987), where it is argued that certain prefixes of Dutch are the predicates of small clauses, and thus elements of syntactic structure. The bound morphemes are brought into their surface position by Head-to-Head movement. The basic idea behind this approach is that generalizations concerning morphological structure and the effects of morphological operations on the syntactic valency of words (their 'external syntax') can be made by means of syntactic mechanisms such as Head-to-Head-Movement which are already available for independent, syntactic reasons. It is the lexicon that specifies that a morpheme is a bound morpheme, i.e. it is subcategorized for appearing together with a morpheme or lexeme under one $\mathrm{X}^{\circ}$ node. Similar proposals to reduce morphology to syntax can be found in Hale \& Keyser (1993). Note that this kind of morphological subcategorization is different from syntactic subcategorization: the morphological subcategorization requirements are not satisfied at D-structure, but at S-structure, unlike what the Projection Principle dictates for syntactic subcategorization (Borer 1991). ${ }^{3}$

The opposite position is taken in Di Sciullo \& Williams (1987). Although they also take a syntagmatic approach to morphology, in their analysis argument structure properties are encoded on both lexical morphemes and affixes, and there is a specific set of principles in the lexical component for computing the argument structure of a derived word on the basis of that of its constituents.

Instead of reducing the effects of morphology on valency to syntactic principles (as in Baker 1988, Hoekstra et al. 1987), or to specific principles of the lexical component (as in Di Sciullo \& Williams 1987) one might also try to reduce them as much as possible to semantics. This is the line taken in Booij (1992): morphology creates derived words with a particular lexical semantics, and there are independently motivated principles ('linking rules') that predict the argument structure of a word on the basis of its meaning. Nevertheless, it appears that certain 'inheritance' phenomena resist a complete reduction of valency effects to semantics. Some affixes are transparent in that they transfer specific subcategorizations of a word to its derivative. For instance, the Dutch adjective tevreden 'content' that is subcategorized for a complement-PP with the preposition met 'with' or the preposition over 'about' transfers this choice of preposition to its derivative tevredenheid (met/over iets) 'contentment with something'. That is, the suffix -heid appears to be transparent in this respect, a fact that has to be accounted for in the morphology module since it does not follow from the lexical 
semantics of tevredenheid that one of the prepositions met or over has to be selected, and that, for instance, van 'of' cannot be used.

The position that morphology cannot be reduced to the syntax of morphemes, which will be defended below, does not imply that morphologically complex words do not have internal constituent structure (contra Anderson 1992). Such constituent structure is sometimes extremely relevant for the explanation of properties of complex words. A syntagmatic notion like 'head', for instance, is indispensable for a proper account of certain properties of compounds such as syntactic category and gender category. The point is rather that constituent structure does not suffice to account for the morphological system of a language.

A diachronic argument for the position that morphology must be at least partially similar to syntax is the phenomenon of grammaticalization, the diachronic change of lexical morphemes into grammatical morphemes, affixes included (cf. Hopper \& Traugott 1993). If there is some truth in Givon's saying that "today's morphology is yesterday's syntax", we should expect structural similarities between syntactic constituents and complex words (Haspelmath 1992). This might also be the explanation for the tendency observed by Greenberg that word order and affix order exhibit certain correlations. ${ }^{4}$

In purely syntactic approaches there is a minimal role for a morphology sui generis in accounting for the order of morphemes anyway: it does not follow from syntactic principles whether a morpheme must be prefixed or suffixed to another constituent. The distinction between prefixes and suffixes, i.e. the direction of attachment of bound morphemes is a matter of morphology proper, of the form of complex words, and not a matter of syntax (Halle \& Marantz 1993). Nor is it always a matter of phonology.

Another example of generalizations concerning the order of morphemes that cannot be reduced to syntactic (or semantic) principles is the phenomenon that languages have purely morphological principles for stacking up affixes. An example is the phenomenon (sometimes expressed by level ordering) that classes of affixes have to be distinguished on the basis of their ordering within a complex word, with a possible correlation with respect to phonological behavior. For example, in English stress-neutral suffixes tend to occur external to stress-shifting suffixes. In the case of English, attempts have been made to translate these generalizations into the word syntax approach by introducing different types of morphological constituent, e.g. roots versus words (Selkirk 1982). As far as Dutch is concerned, it appears that the basic generalization concerning the ordering of suffixes should be stated in terms of a distinction between non-native and native suffixes: native suffixes are peripheral with respect to non-native ones (Booij 
1987, 1995). This is another example of a non-syntactic morphological generalization that underlines the relative autonomy of morphology.

Position class morphology such as that of the Papuan language of Nimboran (Inkelas 1993) is also a clear case of word-internal morpheme ordering that does not follow from syntax or semantics. If there is internal morphological constituency in Nimboran, as advocated by Inkelas, then it is purely morphological constituency that does not reflect syntax or semantics. Similar argumentation for purely morphological constituency on the basis of an analysis of the Amerindian language Potawatomi can be found in Steele (1995).

These phenomena then support Matthews' position that "the structure of the word form must be supplied by statements of a wholly morphological nature" (Matthews 1972:107). Below, I will provide ample evidence for this position.

The problems for a purely syntagmatic approach to morphology are well known since Matthews (1972), and summarized in Spencer (1991) and Anderson (1992): no one-to-one-relation between meaning and form in the realm of inflection (inflectional classes, cumulative and multiple exponence 5 ), nonconcatenative morphology, paradigmatic word formation (Van Marle 1985), empty morphemes (e.g. thematic vowels (Aronoff 1994) and interfixes (Szymanek 1985, Dressler \& Merlini Barbaresi 1991)), allomorphy (Booij 1997), and paradigm structure conditions (Carstairs 1987, Wurzel 1989). All these phenomena suggest the autonomy of certain aspects of morphology.

Halle \& Marantz (1993) is another recent instantiation of the syntagmatic approach, in particular with respect to inflection. Inflectional properties are represented as heads of functional projections in syntactic trees, without a specification of their phonological form (the 'separation hypothesis'). Each morphosyntactic property has its own functional projection. The configurations of such properties as determined by principles of syntax can then be rearranged by a set of Morphological Adjustment rules (merger, fission, and fusion rules), after which the phonological spell out of a particular array of morphosyntactic properties is looked up in the lexicon that specifies the phonological forms of these arrays. Thus, morphology is partially located in syntax, and partially located in a special component of Morphological Adjustment rules. In other words, morphology is distributed across three different modules (syntax, adjustment rules, lexicon), hence the label Distributed Morphology. Noyer (1992) also identifies the autonomous morphology module of the grammar as the module of adjustment rules. The adjustment rules are necessary because morpheme order is not always a direct reflection of the order of the (abstract) morphemes in the hierarchical structure that is assumed on syntactic grounds. The point that the order of inflectional morphemes cannot be completely reduced to principles of syntactic struc- 
ture is also made by Speas (1991) on the basis of an analysis of the inflectional system of Navajo ("morpheme order is constrained by head-to-head movement, but is not completely determined by principles of syntax", Speas 1991:414), and by Spencer (1992).

After this general sketch of the issues involved in determining the (degree of) autonomy of morphology, we will look in detail at allomorphy, and see how these phenomena bear on the autonomy issue.

\section{Allomorphy}

Allomorphy can be accounted for in two ways, depending on its nature. A lot of allomorphy is determined by the phonological rules of a language. Such allomorphy therefore does not bear on the issue of the nature of morphology, and is accounted for in terms of morphophonemic alternations governed by phonological rules. For instance, the allomorphy of the Dutch lexical morpheme naad 'seam' that has two phonetic forms, [nat] and [nad], as in naad [nat] 'seam, sg.' versus naden [nadən] 'seams' follows from the completely transparent phonological rule of Dutch that obstruents are voiceless in coda position.

However, there is also allomorphy for which a phonological account is not self-evident, or even impossible. Let us therefore have a look at the other end of the scale of allomorphy, purely morphologically conditioned allomorphy in the form of systematic variation in the form of stems, a phenomenon for which Aronoff (1994) asked our renewed attention. A typical case of morphologically determined stem allomorphy discussed in Aronoff (1994) is that of Latin. The Latin verbal paradigm exhibits three stems, a present stem for present and past tense, a perfect stem, and a third stem for, among others, the formation of past participles. Thus, the verb armare 'to arm', with the thematic vowel /a/ of the first conjugation, has three stems, arm- $a$ (present stem), arma- $v$ (perfect stem, as in armavi 'I have armed'), and arma-t, as in armatus 'armed'. Many Romance languages have such stem systems in their verbal inflection, e.g. Italian (Dressler \& Thornton 1991, Vogel 1993). ${ }^{6}$ Clearly such rules do not belong to phonology since there is no phonological trigger for this form variation. On the other hand, they are not normal morphological rules because they do not add a meaningful morpheme to a base, but introduce a form change that has no semantic counterpart. For instance, the final /t/ of the third stem does not directly express the morphosyntactic property 'past participle', since this / $t /$ can be used in other morphologically related words as well. For instance, the $/ \mathrm{t} /$ of the past participle delet-us recurs in delet-io 'destruction'.

This kind of allomorphy can have the effect of 'extended exponence' or 'double marking' if there is already a specific morphological marker for a mor- 
phosyntactic category. For instance, the morphosyntactic category Perfect in Latin is expressed twice in the form armavi, by the perfect-specific ending for the 1 st pers. sg. $-i$, and by the selection of a specific $v$-final stem allomorph.

Another wide-spread type of allomorphy is the phenomenon that words have a particular allomorph when they occur in the non-head position of a compound. Bloomfield (1933:225), for instance, observed that Greek nouns have a special 'deriving form' and a 'compounding form' when used in word formation. The word hippos 'horse', for example, occurs as hippo in hippotes 'horseman' and hippo-kantharos 'horse-beetle'. Similarly, Latin nouns often have a special form within compounds. For instance, caper 'goat' has the form capri- in caprimulgus lit. 'goat-milker'. Below, this phenomenon will be discussed in more detail.

In many Indo-European languages stem allomorphy is determined by apophony (Ablaut) which also has a purely morphological function, and is completely comparable to the system of stem formation in Latin, where use is made of segment addition rather than segment change in the case of regular verbs, as we saw above. In present-day Germanic languages these Ablaut patterns are no longer productive, and have to be learned item by item. Nevertheless, Halle \& Marantz (1993) postulate rules to account for these vocalic alternations, dubbed 'readjustment rules' (a term also used by Aronoff (1976) for this kind of alternations), because they want to be able to distinguish such patterns from suppletion of the type go/went in which the stem wen- does not bear any phonological similarity to the stem go. They conclude that "the relations among variants of a given stem in the different morphological contexts can be characterized by means of readjustment rules $[\ldots]$, rules that satisfy the same formal constraints as ordinary phonological rules ..." (Halle \& Marantz 1993:129).

An example of such a 'rule' is the readjustment rule that accounts for the stem /se/ of the verb to say in said, the past tense of say, and in says (Halle \& Marantz 1993:128; the /e/ linked to one x stands for [ $\varepsilon]$ :

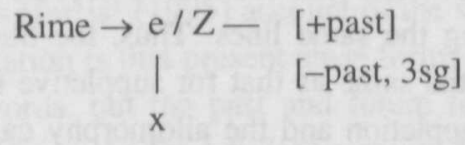

where Z-Rime = say

The alternative approach is listing both stem allomorphs in the lexicon, i.e. both $/ \mathrm{se} /$ and $/ \mathrm{s} \varepsilon /$, and to specify in which inflectional contexts the special stem /se/ occurs. The other stem, /se/ is then to be interpreted as the default stem. Halle \& Marantz' analysis is thus to be seen as an attempt to reduce this kind of stem allomorphy to phonology, albeit a special subpart of it, in which not only reference is made to morphological features, but also to individual lexical morphemes. 
Thus, this is again a form of 'distributed morphology' in that it distributes morphology across different components of the grammar, and relegates morphologically conditioned allomorphy to a readjustment rule part of the phonological module.

Some comments are in order on this account of stem allomorphy. Halle \& Marantz's reasoning presupposes that there is a sharp demarcation between stem allomorphy and suppletion, which I doubt. For instance, the Dutch verb gaan 'to go' with the stem $/ \mathrm{\gamma a} /$ has the allomorph ging $/ \mathrm{y}$ II $/$ in the past tense. There is some phonological similarity between the two forms, yet, it is very cumbersome to express this similarity in terms of rules. Therefore, traditionally it is called partial suppletion. The pair say/said could also be considered a case of partial suppletion. The obvious solution seems to be to list both stems in the lexicon, and to add a subcategorization to the non-default one.

If we list both allomorphs, there are still two possibilities of interpretation. For instance, we may qualify a form such as Dutch liep 'walked, sg.' as the past tense allomorph of the verb loop followed by a past tense suffix $\varnothing$, or consider liep as the direct expression of 'walk, past tense'. In both interpretations, the expression for number is $\emptyset$, as is the case for regular verbs:

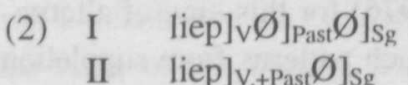

That the first interpretation is possible, is supported by the observation that during the process of language acquisition, Dutch children use the form liepte besides the correct form liep and the overregularized form loopte. The addition of the regular past tense suffix - $t e$ is only possible under a stem allomorph interpretation of liep. Since adults only use liep, this suggests that they interpret this form as the direct expression of 'loop, past tense'. If that is the case, the addition of the regular past tense suffix - $t e$ is predicted not to occur since the word in question is already specified for the property 'past tense'. The non-occurrence of feets as the plural form of foot can be explained along the same lines. Thus, the blocking effects related to such irregular forms are the same as that for suppletive forms. The difference between (full or partial) suppletion and the allomorphy cases of the type loop/liep is that for the latter a formal regularity can be stated in terms of a redundancy rule (Jackendoff 1975), because there are sets of irregular verbs that exhibit the same vocalic alternation.

The advantage of listing each allomorph as a separate underlying representation is that it then follows that the 'rules' involved are always structurepreserving, i.e. they only introduce segments that belong to the set of contrastive, underlying segments of the language (Spencer 1988). It also predicts that allomorphy rules can never apply in between phonological rules, i.e. that the state- 
ment of allomorphy regularities never depends on the previous application of automatic phonological rules.

The attempt to reduce allomorphy as much as possible to phonology is a hallmark of classical generative phonology. The basic option taken by SPEphonology is to assume abstract underlying representations so that, for instance, sign and signal share a morpheme sign with a unique underlying representation /sign/ from which the two phonetic forms [sain] and [sign] can be derived. In addition, phonological rules are also allowed to refer to non-phonological information such as the morphological structure of a word, and to word category labels. The successor to SPE as far as the interaction of phonology and morphology is concerned, Lexical Phonology, is a sophisticated attempt to explain allomorphy as much as possible as the effect of lexical phonological rules by making use of principles such as the interwovenness of morphology and phonology and its consequence of cyclic rule application, the Derived Environment Condition (Strict Cyclicity), and level ordering. For instance, the loc. sg. suffix $-e$ in the Polish word servis $+e$ 'service' triggers palatalization of the preceding /s/, whereas the word-initial /s/ does not palatalize although it is also followed by an /e/. Thus, it seems that this kind of palatalization is triggered by a particular suffix, or that this suffix requires a particular allomorph of the stem. The explanation proposed in Rubach (1984), however, is different, and purely phonological: palatalization is a cyclic phonological rule subject to the Derived Environment Condition; therefore, it is only the second /s/ that palatalizes, and palatalization of the first $/ \mathrm{s} /$ is blocked due to this condition. Thus, the rule of palatalization can be kept as a purely phonological rule that does not refer to morphological information. Nevertheless, even in Lexical Phonology some lexical phonological rules have to refer directly to morphological information (cf. Booij 1994 for a survey of Lexical Phonology).

Another example of a phonological interpretation of stem allomorphy is James Harris' (1995) account of the stress patterns of verbs in Spanish. The generalization is that present tense forms have the same stress pattern as other Spanish words, but the past and future forms are different: in past forms the main stress is on the final syllable, and in future forms it is on the first syllable of the future ending. Harris does not assume three different verbal stems, as in Latin; instead, the past tense morpheme is lexically specified as having a monosyllabic foot, and the future tense morpheme as beginning with a (normal, trochaic) foot. These lexically specified feet then block application of the Main Stress Rule that assigns a trochaic foot at the right edge of each word.

The issue of how to deal with allomorphy is an important one for the delimitation of morphology with respect to phonology (cf. Dressler 1985), and a num- 
ber of recent publications show this awareness. For instance, in his introduction to the The Handbook of Phonological Theory, Goldsmith made the following remark:

\footnotetext{
"The reader of this volume will find none of the contributors worrying about the possibility that phonological theory has been forced to deal with empirical problems that ought rather be taken care of by morphological theory, and this lack of worry is surprising [...]. The motto "minimize allomorphy" remains today's watchword, in the sense that in practice, morphology continues to be concerned with the linear order and constituent structure of words, and with making a choice of which morphemes are to be employed to realize a set of morphosyntactic features in a given sentence; but contextually determined variations in the realization of a given morpheme will to the extent possible be accounted for phonologically." (Goldsmith 1995:9).
}

On the same page, Goldsmith rightly qualifies Lexical Phonology as "a theory of the phonologization of alternations". John Harris (1994) is one of the many linguists who do not accept this strategy of 'minimize allomorphy' in all cases. $\mathrm{He}$ takes the position that alternations such as English Velar Softening and Vowel Shift are not to be accounted for by phonological rules: "the relatedness of such alternants must then be captured by non-phonological means, for example through non-derivational lexical rules or by reference to some notion of proximity in lexical storage" (Harris 1994:26-27).

Similar conclusions have been drawn by Lieber (1980) with respect to German Umlaut alternations, by Spencer (1988, 1991:100), and by Mohanan (1995). Spencer $(1988,1991: 123-24)$ argued that certain types of stem allomorphy cannot be dealt with in terms of rules of phonology. He therefore proposed to assume 'morpholexical rules' that relate two or more stems listed in the lexicon. Thus the selection of the proper allomorph in such cases is not necessarily a matter of phonology; it can also be a matter of morphology, and detailed investigations as to their demarcation are necessary.

A case from Dutch where it can be shown that a stem allomorphy analysis is to be preferred to a phonological analysis is formed by the alternation between short and long vowels in non-native nouns ending in -or or -on. This vowel length alternation occurs optionally in singular-plural pairs:

\begin{tabular}{|c|c|}
\hline $\begin{array}{l}\text { singular } \\
\text { dém[o]n 'demon' } \\
\text { eléktr[o]n 'electron' } \\
\text { mót[ग]r 'engine' } \\
\text { dóct[o]r 'doctor' }\end{array}$ & 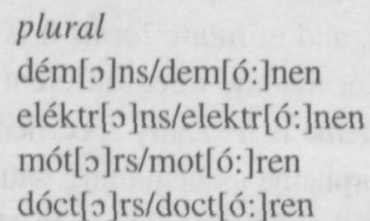 \\
\hline
\end{tabular}

The allomorph with the long vowel is also used in non-native word formation, for instance with the suffix -isch, whereas the allomorph with the short vowel is used in combination with native suffixes: 


\section{(4) $\operatorname{dem}[\mathrm{o}:] \mathrm{n}$-isch 'demonic' \\ elektr[o:]n-isch 'electronic' \\ $\operatorname{mot}[0:] r-i s c h$ 'engine-' \\ $\operatorname{doct}[0:] \mathrm{r}$-aal 'doctor-'}

The crucial observation is that the difference in the form of the plural suffix correlates with a difference in the location of the main stress, although normally plural suffixes do not affect the stress patterns of their base words. The suffix $-s$ is added after an unstressed syllable, and the suffix -en after a stressed syllable. The result is that the plural noun always ends in a trochee.

In a phonological analysis, after the attachment of the plural suffix -en, we must first apply the - clearly non-automatic - rule of vowel lengthening that lengthens the vowel in open syllables. Subsequently, the main stress rule of Dutch must apply, which assigns main stress to the penultimate syllable of the word. That is, extrinsic ordering of phonological rules is required. Moreover, we do not express the relation between the choice of the particular suffix and the stress pattern involved. On the contrary, the analysis forces us to violate the constraint that -en can be selected only when the stem ends in a stressed syllable. On the other hand, these facts follow directly if we assume two allomorphs for these words. The only exceptional aspect of the behavior of these words in -on and -or then is that the allomorph that is normally used for non-native suffixation only, may also be used for inflectional suffixation which is not non-native. When the allomorph demon is used, the prosodic constraint on plural nouns requires $-s$, because the predictable stress pattern is démon. The allomorph demoon, on the other hand, will receive main stress on its final syllable, because this syllable is superheavy (long vowel followed by a consonant), and thus forms a foot of its own. Thus, it will require the plural suffix -en.

\subsection{Allomorphy as a reflex of language history}

As already mentioned above, stem allomorphy often reflects the phonological history of a language, but then is no longer transparent synchronically. For instance, the English Vowel Shift was once an active process, but this is no longer the case. Thus, phonologically conditioned allomorphy becomes morphologically conditioned allomorphy. A similar example comes from Frisian. In Frisian, there was a phonological process of breaking, the development of homorganic glides before long mid vowels, with the concomitant shortening of this vowel, resulting in 'broken diphthongs' (Tiersma 1983:60): 


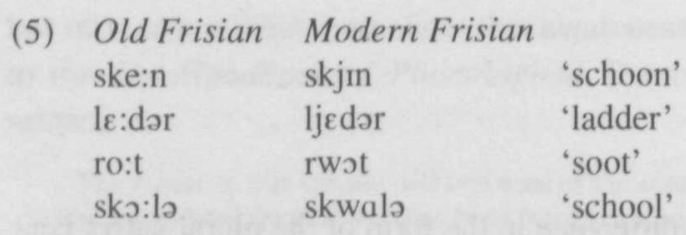

The two types of stem alternate in Modern Frisian in a number of morphological contexts, among which the following (data from Tiersma 1983):
a. comparative
$\begin{array}{ll}\text { leaf 'dear' } & \text { ljevver 'rather' } \\ \text { fier 'far' } & \text { fjirder 'farther' }\end{array}$
b. nominalization
wiet 'wet' wjitte 'wetness'
fier 'far' fjirte 'distance'
c. pluralization
stien 'stone' stjinnen pl.
beam 'tree' bjemmen pl.
d. diminutive formation
stien 'stone' stjintsje dim.
beam 'tree' bjemke dim.
e. compounds
beam 'tree'
hea 'hay'
bjemtâke 'tree branch'
hjefwarke 'hay fork'

This alternation, however, is no longer a synchronic rule of Frisian: speakers of Frisian have to memorize which words exhibit breaking, and in which morphological contexts. Younger speakers of Frisian often coin compounds without breaking. For instance, they may use the form beamtûke 'tree branch' instead of bjemtûke.

Dutch also has an abundance of such synchronic reflexes of historical phonology. A first example is the process of schwa-apocope that deleted word-final schwas of nouns. As a result, in present-day Dutch some nouns have two forms, others do not. In some cases, the two different forms have developed into two different lexical items with different meanings, as in groeve 'grave' versus groef 'groove', which supports the assumption that both allomorphs are listed in the lexicon. If such words did not have two different representations in the mental lexicon of native speakers, a historical development in which they became two different lexical items is not interpretable. In addition, for some nouns it is only the short or the long form that may be used as the first constituent of complex words. 
(7) schande/*schand 'shame' aarde/*aard 'earth' armoede/*armoed 'poverty'

ere/eer 'honour'

einde/eind 'end' vreugde/vreugd 'joy' *schande-knaap/schand-knaap 'catamite'

*aarde-bei/aard-bei 'strawberry'

*armoede-zaaier/armoed-zaaier

'down-and-out-er' ere-schuld/*eer-schuld 'debt of honour' *einde-oordeel/eind-oordeel 'final verdict' vreugde-vuur/*vreugd-vuur 'bonfire'

Even in head position the choice of an allomorph may be lexically governed.

(8)

$$
\begin{aligned}
& \text { *gifte/gift 'id.' } \\
& \text { *lage/laag 'layer' }
\end{aligned}
$$

aan-gifte/*aan-gift 'declaration' uit-gifte/*uit-gift 'issue' *melk-gifte/melk-gift 'milk production'

oplage/oplaag 'edition' bijlage/*bijlaag 'supplement'

Similar patterns of lexically determined choice of a particular allomorph can be seen for words that were once subject to de-deletion:

(9) weide/wei 'meadow' schade/scha 'damage' zijde/zij 'side' armoede/armoe 'poverty'

$$
\begin{aligned}
& \text { *weide-land/wei-land 'pasture' } \\
& \text { schade-claim/*scha-claim 'insurance claim' } \\
& \text { *zijde-kant/zij-kant 'side' } \\
& \text { armoede-grens/*armoe-grens 'poverty line' }
\end{aligned}
$$

Note that armoede 'poverty' has three allomorphs: armoede, armoed, armoe, of which armoed only occurs in a particular compound, armoedzaaier 'down-andout-er'.

In sum, it appears that this kind of alternation which is no longer productive, cannot be accounted for by means of phonological rules. Instead, the allomorphs have to be listed, and it has to be specified which allomorph is to be used where. Usually, one of the allomorphs is the default one, whereas the other has/have a specific subcategorization. ${ }^{7}$ When the subcategorization is morphological in nature, we thus meet with a case of 'pure' morphology, a formal regularity that is neither conditioned by phonology nor a matter of a systematic form-meaning relationship. The formal relatedness between the two listed allomorphs can only be expressed in the form of static redundancy rules.

In some cases of allomorphy, it does not make sense to formulate a rule, although there is a transparent regularity involved. For example, Dutch, like many other European languages, has the prefixes a/an and de/des. The vowel-final allomorphs appear before a consonant-initial stem, and the consonant-final ones before a vowel-initial stem:

(10) a-moreel 'immoral', an-organisch 'anorganic'

de-motivatie 'demotivation', des-integratie 'disintegration' 
Since there is only one morpheme involved in, for instance, the $\varnothing / n$ alternation, it does not make sense to assume a morpholexical rule. That is, we list both allomorphs, and provide one of them with a phonological subcategorization. Such phonologically governed allomorph selection may also play a role in syntactic contexts, as is the case for the choice between $a$ and $a$ as indefinite determiner in English: $a$ before consonants, an before vowels (Zwicky 1985).

Stem allomorphy may also reflect the morphological history of the language. This is the case for Germanic languages such as German, Norwegian, and Dutch in the case of compounds. The first constituent of Dutch nominal compounds may have an extension which was originally a case ending because some of these compounds arose through reinterpretation of phrases (Van Loey 1964:179).

(11) dat her-en huis 'the gentleman's house' $>$ dat herenhuis

die conin[k-s] crone 'the king's crown' > die conin[ks]crone

die siele- $n$ rust 'the soul's rest' > die sielenrust

This kind of allomorphy was then extended, and became part of the system of compounding. Below, we will return to the nature of the regularities involved here. Interestingly, this allomorphy is not only found in compounding, but also in derived words with a suffix that behaves like a prosodic word of its own, such as -achtig '-like' or -loos '-less' (both suffixes derive historically from words).

(12) voorjaar-s-achtig 'spring-like', kruidenier-s-achtig 'grocer-like'; arbeid-s-loos 'without work', vaderland-s-loos 'without home country', wrijving-s-loos 'friction-less'

That is, the extended allomorphs have to be subcategorized as bound forms that occur before another prosodic word in the same morphological word.

A third historical source of stem allomorphy is the borrowing of non-native words from Greek, Latin and French into Dutch. Since both simplex and complex words were borrowed, and the source language already exhibited this allomorphy, this created an enormous number of words with two stem allomorphs, a default form, and one that is to be used in non-native word formation:

\begin{tabular}{|c|c|}
\hline $\begin{array}{l}\text { simplex word } \\
\text { ratio 'id.' }\end{array}$ & $\begin{array}{l}\text { derived words } \\
\text { ration-eel 'rational', ration-alist 'id.' }\end{array}$ \\
\hline $\begin{array}{l}\text { Plato 'id.' } \\
\text { conditie 'condition' } \\
\text { drama 'id.' }\end{array}$ & $\begin{array}{l}\text { platon-isme 'platonism', platon-isch 'platonic' } \\
\text { condition-eer 'to condition', condition-eel 'conditional' } \\
\text { dramat-isch 'dramatic', dramat-iseer 'dramatize', } \\
\text { dramat-urg 'dramatist' }\end{array}$ \\
\hline $\begin{array}{l}\text { ras 'race' } \\
\text { complex 'id.' }\end{array}$ & $\begin{array}{l}\text { rac-iaal 'racial', rac-isme 'racism', rac-ist 'id.' } \\
\text { complic-eer 'to complicate', complic-atie } \\
\text { 'complication' }\end{array}$ \\
\hline publiek 'public' & public-eer 'to publish', public-ist 'writer' \\
\hline
\end{tabular}


monster 'id.' monstru-eus 'monstrous'

minister 'id.' minister-ie 'ministry', minister-ieel 'ministerial'

Why do we not assume one underlying form for Plato, /pla:to:n/, and a phonological rule that deletes word-final $/ \mathrm{n} /$ ? The answer is that, even in the nonnative part of the Dutch vocabulary, many words ending in a long vowel $+/ \mathrm{n}$ / keep this /n/, e.g. anemoon 'anemone', cycloon 'cyclone', and demoon 'demon'. A phonological analysis would moreover require extrinsic ordering of the $/ \mathrm{n} /$ deletion rule before stress assignment since an $/ \mathrm{n} /$ makes the last syllable superheavy, and thus would attract, incorrectly so, main stress to the final syllable of Pláto.

Another type of alternation in borrowed words is that between zero and schwa in words such as the following:

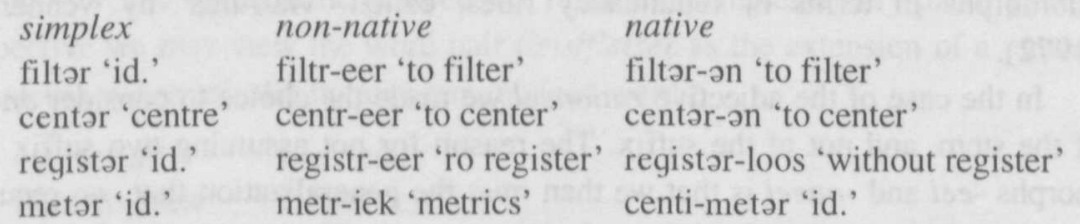

The generalization is that native morphology chooses the allomorph that is a pronounceable, proper prosodic word, whereas the non-native morphology uses an allomorph that ends in a consonant cluster/tr/ that cannot form a coda, and hence is unpronounceable. Therefore, the default vowel of Dutch, the schwa, has to break up this cluster unless it is followed by a vowel-initial non-native suffix. A phonological account of this alternation would read as follows: there is a rule of schwa epenthesis ordered after level 1, the non-native morphology, and before level 2 , that of the native morphology of Dutch. The rule inserts a schwa before an extrasyllabic consonant.

However, there are also cases where another solution is chosen:
orkest 'orchestra' orkestr-eer 'to orchestrate' equilibrium 'balance' equilibr-eer 'to balance'

In these cases, there is no phonological regularity involved in the relation between the form of the base as an independent word, and the form of the base as part of a complex word. The only reasonable account is listing two allomorphs for each of these non-native words, one of them being subcategorized for nonnative suffixes.

These three types of allomorphy show that stem allomorphy is not restricted to inflectional systems, but also plays an important role in compounding and derivation. The only way of accounting for the first type (reflex of historical phonological processes) and the third type (borrowing) is to list both stems in the 
lexicon, and to add a subcategorization feature to one of them. For instance, the allomorph schand of schande must be subcategorized for occurring in the nonhead position of compounds (schandknaap, schandvlek, schanddaad), where schande is the default form, which occurs as independent lexeme, in the head position of compounds, and in derivation (schandelijk). Similarly, in the case of ratio we will have to list the stem allomorph ration with the following subcategorization: [- suffix $\left._{\text {[-native] }}\right]$.

It does not make sense to postulate a rule, for which ratio would be marked, that inserts on before non-native suffixes, because it is not a rule. Rather, we would like to relate such stem allomorphs by means of a redundancy rule. In the case of the stem allomorphy resulting from de-deletion discussed above, Zonneveld (1978) already proposed to express the relationship between such stem allomorphs in terms of redundancy rules, called 'via-rules' by Vennemann (1972).

In the case of the adjective rationeel we made the choice to consider on part of the stem, and not of the suffix. The reason for not assuming two suffix allomorphs -eel and -oneel is that we then miss the generalization that -on recurs in every complex word derived from the lexeme ratio. The same holds for the other examples given. In other cases, the situation can be different. Above, we also met with affixes with two allomorphs.

In conclusion, there is a vast amount of allomorphy involved in computing the correct formal shape of complex words that does not follow from the (lexical) phonology of the language involved, and which therefore belongs to the realm of morphology. This aspect of the form of complex words can therefore not be subsumed under phonology, and is evidence for an autonomous morphological module of the grammar.

\section{Paradigmatic Allomorphy}

In this section, I will argue that allomorphy phenomena provide even more evidence for the autonomy of morphology in that certain regularities in the choice of particular allomorphs can not only not be reduced to phonology, but presuppose that the existing words of a language form a network of paradigmatic relations. Before discussing such facts in detail, I will make some remarks on paradigmatic morphology in general, in order to provide the relevant background.

\subsection{Paradigmatic word formation}

Complex words can be analyzed from two (in principle complementary) perspectives. In the syntagmatic perspective, a complex word is a concatenation of morphemes. In the paradigmatic perspective, on the other hand, a complex word is 
seen as a member of a morphological category, i.e. of a class of words in which a certain formal structure systematically corresponds with a certain semantic structure. The paradigmatic perspective is output-oriented in that it analyses form-meaning correspondences in existing words, and investigates how these correspondences can be extended to new words. The necessity of allowing for word formation that can only be based on paradigmatic relations between words is another argument for the existence of an autonomous morphological module, because, crucially, the word formation patterns involved cannot be reduced to the concatenation of morphemes.

Let us first look at a simple example of a word formation pattern that can be viewed from both perspectives, the derivation of the noun fietser from the verbal stem fiets. In this case, we may view fietser as the result of the concatenation of fiets and -er, the syntagmatic perspective. From the complementary paradigmatic perspective we may view the word pair fiets/fietser as the extension of a pattern that occurs systematically in quite a number of words:
eet 'to eat'
eter 'eater'
fiets 'to cycle'
fietser 'cyclist'
werk 'to work'
werker 'worker'

When we have a new verb such as bingo 'to play bingo', the noun bingoër can be formed as an extension of the pattern:

(17) eet: eter $=$ bingo: $\mathrm{X}$

In a number of cases a paradigmatic analysis of word formation appears to be the only one that can explain the regularities observed. For instance, the verb komen 'to come' has kom-st as it corresponding noun. Deverbal nominalization by means of -st is unproductive in present-day Dutch; yet we find systematically nouns with -st in the case of (separable complex) words with komen as their base, and the pattern can be extended when new (separable complex) verbs arise:

$\begin{array}{ll}\begin{array}{l}\text { aan-komen 'to arrive' } \\ \text { bijeen-komen 'to meet' } \\ \text { binnen-komen 'to enter' }\end{array} & \begin{array}{l}\text { aankomst 'arrival' } \\ \text { bijeenkomst 'meeting' } \\ \text { binnenkomst 'entrance' } \\ \text { door-komen 'to pass' }\end{array} \\ \begin{array}{l}\text { doorkomst 'passage' } \\ \text { overen-komen 'to agree' } \\ \text { overeenkomst 'agreement' } \\ \text { terug-komen 'to return' }\end{array} & \begin{array}{l}\text { samenkomst 'meeting' } \\ \text { terugkomst 'return' }\end{array} \\ \begin{array}{l}\text { uit-komen 'to result' } \\ \text { voorbij-komen 'to pass' }\end{array} & \text { voorbijkomst 'passage' } \\ \text { weder-komen 'to return' } & \text { wederkomst 'return' }\end{array}$


Similar patterns can be observed for a number of other Dutch verbs with an irregular, unproductive type of nominalization, e.g. those with the particle op:

$$
\begin{array}{ll}
\text { op-staan 'to rise' } & \text { op-stand 'uprising' } \\
\text { op-slaan 'to store' } & \text { op-slag 'storage' } \\
\text { op-geven 'to assign' } & \text { op-gave 'assignment' } \\
\text { op-zien 'to supervise' } & \text { op-zicht 'supervision' } \\
\text { op-gaan 'to ascend' } & \text { op-gang 'ascent' }
\end{array}
$$

In all these examples, the complex noun cannot be interpreted as a case of compounding with the deverbal noun as the head, because the meanings of these complex verbs are idiosyncratic, and it is these idiosyncratic meanings that recur in the complex nouns. Therefore, the complex verbs are the bases of these nominalizations.

The same pattern of paradigmatic word formation for the German counterparts of such cases is observed by Becker (1993:15-16):

$\begin{array}{ll}\text { (20) verb } & \text { deverbal noun } \\ \text { geben 'to give' } & \text { Gabe } \\ \text { abgeben 'to hand over' } & \text { Abgabe } \\ \text { durchgeben 'to pass' } & \text { Durchgabe } \\ \text { ziehen 'to draw' } & \text { Zug } \\ \text { abziehen 'to draw off' } & \text { Abzug } \\ \text { aufziehen 'to draw up' } & \text { Aufzug }\end{array}$

Note also that we cannot take recourse here to a solution advocated by Stump (1995) for inflection. Stump observed that the morphological head of a complex word is always inflected in the same way as when the head word occurs as a simplex word. For instance, the (irregular) past tense of become is the same as that of come: came/became. Stump therefore proposed a principle of 'Uniform Head Marking' for inflectional morphology. However, in the case discussed above, we are dealing with derivational morphology, and the selection of a particular form for the deverbal nominalization of both geben and abgeben does not follow from this principle. ${ }^{8}$

The observations on paradigmatic word formation, i.e. morphology that is output-based instead of being input-based imply that morphological operations can be based on the network of paradigmatic relations between words (Van Marle 1985). This supports the claim that morphology is a module sui generis that cannot be equated with 'the syntax of morphemes'.

\subsection{Allomorphy and paradigmatic relations}

An example of paradigmatically determined allomorphy is the role of the feminine form of French adjectives in derivation: the adverbial suffix -ment is always 
added to the feminine form of the adjective without a feminine meaning being implied:

(21) masc.

fem. adverb

$\begin{array}{lll}\text { faux 'false' } & \text { fausse } & \text { faussement } \\ \text { lent 'slow' } & \text { lente } & \text { lentement } \\ \text { heureux 'happy' } & \text { heureuse } & \text { heureusement } \\ \text { certain 'id.' } & \text { certaine } & \text { certainement }\end{array}$

In these cases one could still defend a non-paradigmatic approach by assuming a latent stem-final consonant which then surface before the suffix -ement, just as it surfaces before the suffixes $-e$ and -esse. This analysis, however, fails to explain why, if an adjective has a suppletive or irregular feminine form, it is this suppletive form that shows up in the adverb in -ment:

$\begin{array}{lll}\text { masc. } & \text { fem. } & \text { adverb } \\ \text { beau 'beautiful' } & \text { belle } & \text { bellement } \\ \text { blanc 'white' } & \text { blanche } & \text { blanchement } \\ \text { fou 'stupid' } & \text { folle } & \text { follement } \\ \text { sec 'dry' } & \text { sèche } & \text { sèchement } \\ \text { vieux 'old' } & \text { vieille } & \text { veillement }\end{array}$

These 'feminine' allomorphs also show up in other types of deadjectival words. Therefore, the only generalizing analysis is that in which an allomorph that is formally identical to the feminine form of the adjective is the formal basis for derivation. $^{9}$

The same allomorphy pattern is found in related languages such as Spanish, as in clar-a-mente 'clearly', with the feminine suffix - $a$. As Rainer (1993b:267) pointed out, this feminine suffix reflects the historical origin of the suffix -mente which is a case form of Latin mens, mentis 'mind', a feminine noun that requires the modifying adjective to agree in gender, as in clara mente 'with a clear mind'.

In Booij (1997) I discussed a number of cases in which the particular allomorph of a base word to be chosen for a word formation process has to be identified as the same form as that of another word formed from that base word. For instance, I showed that the formal base for coining Dutch geographical adjectives is not the corresponding name of the country, but the name of the corresponding inhabitant's name:

(23) country

Amerika 'America'

Zweden 'Sweden'

Griekenland 'Greece'

Israel 'Israel'

Rusland 'Russia'

$\begin{array}{ll}\text { inhabitative } & \text { adjective } \\ \text { Amerikaan } & \text { Amerikaan-s } \\ \text { Zweed } & \text { Zweed-s } \\ \text { Griek } & \text { Griek-s } \\ \text { Israeliet } & \text { Israelit-isch } \\ \text { Rus } & \text { Russ-isch }\end{array}$


A similar observation with respect to the coining of German geographical adjectives has been made in Becker (1990:43), who argues that such adjectives are made by replacement of $-e r$ or $-e$ by $-i s c h$ :

\begin{tabular}{|c|c|c|}
\hline untry & inhabitative & adjective \\
\hline 'Bol & Böhme & böhmisch \\
\hline The & Thebaner & inisch \\
\hline 'Cyprus’ & Zypriote & zypriotisch \\
\hline rankreich 'France' & Franzose & anzösisch \\
\hline
\end{tabular}

Becker does not draw the conclusion, however, that the form of the inhabitative minus -e/-er functions as stem allomorph for the adjective. This latter interpretation is the one I prefer, and is based on the semantic argument that the adjective pertains to the country, not to the inhabitant. These patterns of word formation show that there is not always a simple relation between form and meaning in morphology: certain formal regularities do not reflect semantic regularities.

Another relevant case is that of the five verbs of Dutch which are special in that they have an infinitive form in $-n$ instead of the regular - en:

(25) doen 'to do'
gaan 'to go'
slaan 'to hit'
staan 'to stand'
zien 'to see'

These verbs have a second stem which is formally identical to the (irregular) infinitival form, and functions as the verbal base for the formation of the present participles and for derivation (Booij 1997). Crucially, we cannot say that the relevant words are derived from the infinitive, as De Haas \& Trommelen (1993:242) claimed as far as suffixation with -ing is involved, as in:

(26) be-doen-ing 'to-do'

vol-doen-ing 'satisfaction'

aan-doen-ing 'affliction'

boete-doen-ing 'penance'

voor-zien-ing 'provision'

her-zien-ing 'revision'

because the Dutch suffix -ing is a deverbal suffix, whereas the infinitive behaves as a noun in word formation (Booij 1989). Similarly, in the case of deverbal adjectives in -baar such as gang-baar 'current' and zicht-baar 'visible' they speak of attachment of -baar '-able' to a related substantive (De Haas \& Trommelen 1993:293). Again, such an analysis does not explain why the categorial restriction on -baar that it is to be attached to a verb, can be violated in these cases. 
This situation thus reminds us of the cases discussed in Aronoff (1994). For instance, in the case of Latin deverbal nouns like dele-t-io which have the same stem extension $t$ as the past participle (dele-t-us), we do not want to say that the deverbal noun is derived from the past participle since the semantics of the past participle does not play a role, but rather that the past participle and the deverbal noun share the same stem, the third stem that has a predictable final $-t$.

When we look in more detail at the verbal derivations of these five verbs of Dutch, it appears that they do not only have a second stem that is formally identical to the infinitive, but also a third allomorph which is formally identical to the deverbal noun of these verbs: ${ }^{10}$

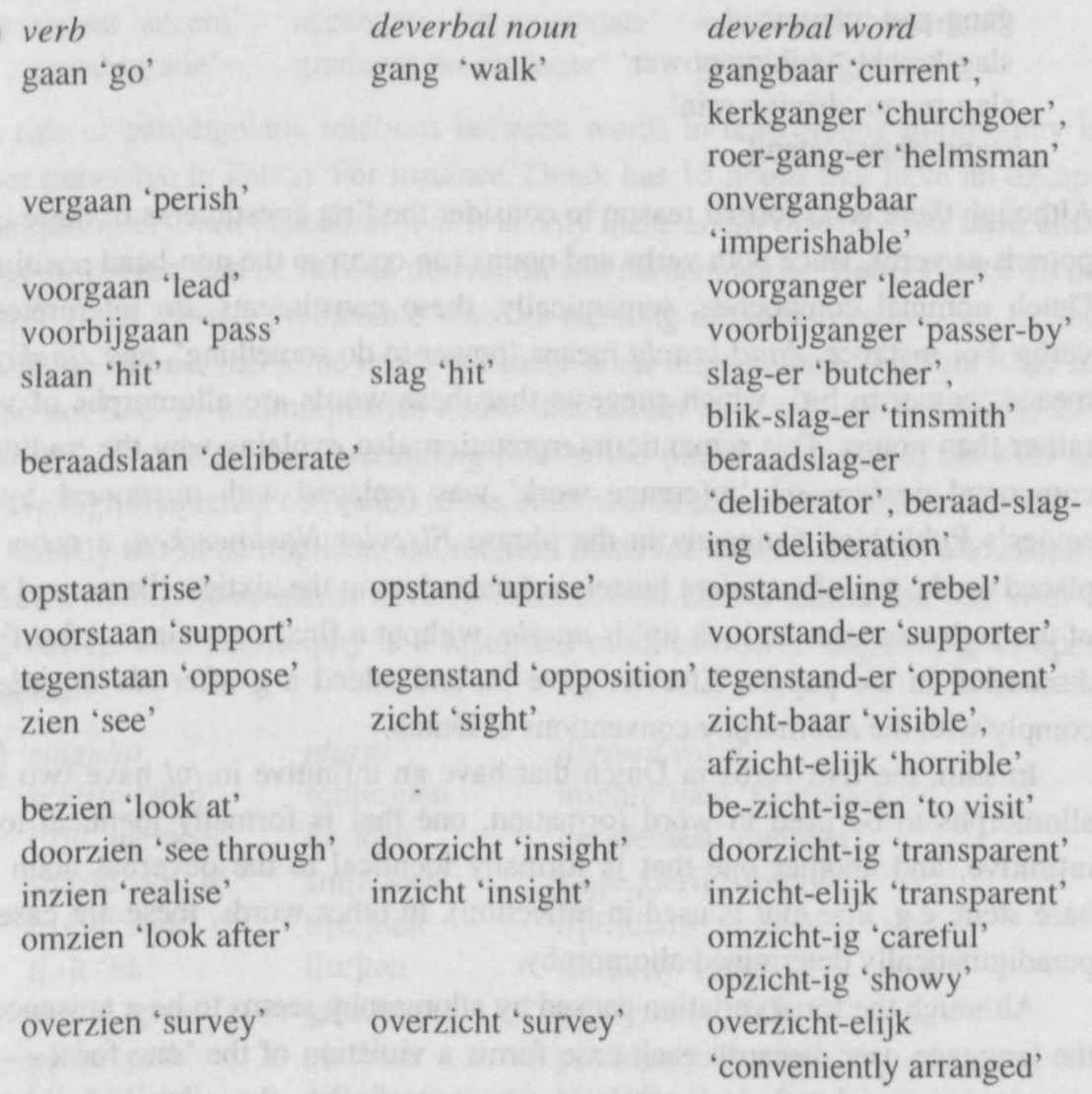

In a number of cases the stems involved in the derivation of the words in the third column cannot be nouns because the suffixes involved attach only to verbs. The suffix -baar, for instance, is an exclusively deverbal suffix, and hence, the stem zicht in zichtbaar 'visible' cannot be interpreted as a noun. This is not the case for all suffixes, however. For instance, -eling attaches both to verbs and nouns, 
and therefore, opstandeling 'rebel' could be analyzed as being derived from the deverbal noun opstand 'uprise'. Another formal argument for the allomorphy interpretation of these facts is that we have pairs like the verb voorstaan and the agent noun voorstander, but we do not have the noun voorstand. Therefore, voorstander must have been derived from the verb, but with the stem allomorphy discussed here.

The stem allomorphy discussed here also occurs in compounds. Dutch nominal compounds can have verbs as their first constituent. Observe now the following compounds:

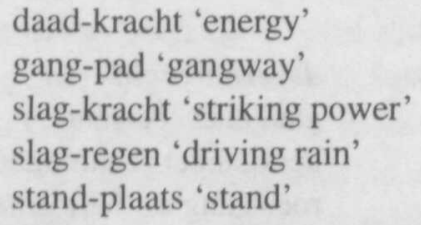

Although there is no formal reason to consider the first constituents of these compounds as verbs, since both verbs and nouns can occur in the non-head position of Dutch nominal compounds, semantically, these constituents are interpreted as verbs. For instance, daad-kracht means 'power to do something', and slagkracht means 'power to hit', which suggests that these words are allomorphs of verbs rather than nouns. This semantic interpretation also explains why the traditional compound naslagwerk 'reference work' was replaced with naslawerk by Elsevier's Publishing Company in the phrase Elsevier Naslawerken, a neon sign placed on the top of a student hostel in Amsterdam in the sixties: the normal stem of the verb na-slaan 'to look up' is na-sla, without a final consonant. After fierce discussion in the papers, Elsevier gave in, and added a $g$ after sla in order to comply with the allomorphy conventions of Dutch.

In sum, the five verbs in Dutch that have an infinitive in $/ \mathrm{n} /$ have two stem allomorphs to be used in word formation, one that is formally identical to the infinitive, and another one that is formally identical to the deverbal noun (the bare stem, e.g. doe /du/ is used in inflection). In other words, these are cases of paradigmatically determined allomorphy.

Although the form variation caused by allomorphy seems to be a nuisance for the language user, because each case forms a violation of the 'one form - one meaning' principle, there is at least one consolation: the allomorphs can be learned on the basis of the form of other words in the lexicon, which have to be learned anyway.

This role of paradigmatic relations in discovering the correct stem allomorph is also shortly mentioned by Rainer (1993b:155) who observed that when Span- 
ish adjectives in - $a l$ are preceded by an $u$, this $u$ often also occurs in the corresponding verb:

(29) acentual/acentuar, gradual/graduar, habitual/habituar

and he notes that "in diesem Fall mag man also schon fast eine regelmässige Querverbindung zwischen Wörtern des Typs Xual und solchen des Typs Xuar annehmen" (Rainer 1993b:155). This regularity is probably a 'pan-European' one since it also occurs in the Romance stratum of the lexicon of Germanic languages such as English and Dutch. The following words are the counterparts in Dutch:

(30) accent 'accent' graad 'grade' accentueer 'to accentuate' gradueer 'to graduate' accentueel 'accentual'

gradueel 'gradual'

The role of paradigmatic relations between words in determining allomorphy is rather pervasive in Dutch. For instance, Dutch has 15 nouns that have an exceptional plural in -eren instead of -en. It is only these nouns that have an stem allomorph in -er that can be used in derivation and compounding (Booij 1997). To be sure, it is not always predictable whether the long allomorph (with -er), or the default, short one, has to be used, but there is an implicational relation. That is, we do not find -er-allomorphs for nouns that do not have a plural form with this allomorph. Probably, the determining role of the plural form has to do with its relative high frequency compared to the other words coined from the same stem.

Exactly the same implicational relation holds for another form of allomorphy in Dutch nouns: some stems have two forms, one with a short, and one with a long vowel. This allomorphy is a historical relict of vowel lengthening in open syllables.

\begin{tabular}{|c|c|c|}
\hline singular & plural & derived word \\
\hline $\operatorname{sch}[1] p$ 'ship' & sch[e:]pen & insch[e:]pen 'to embark' \\
\hline I[r]d 'member' & 1[e:]den & I[e:]demaat 'member' \\
\hline sm[I]d 'smith' & sm[e:]den & sm[e:]derij 'smithy' \\
\hline $\operatorname{tr}[\varepsilon] \mathrm{d}$ 'step' & $\operatorname{tr}[\mathrm{e}:] d e n$ & $\operatorname{tr}[\mathrm{e}:] \mathrm{den} \mathrm{V}_{\mathrm{V}}$ 'to tread' \\
\hline I[o]t 'id.' & $1[0:] \operatorname{ten}$ & I[o:]terij 'lottery' \\
\hline gr[a]f 'grave' & gr[a:]ven & gr[a:]ven $_{\mathrm{v}}$ 'to dig' \\
\hline $\mathrm{p}[\mathrm{a}] \mathrm{d}$ 'path' & p[a:]den & p[a:]dje 'path, dim.' \\
\hline bl[a]d 'leaf' & bl[a:]den & bl[a:]dje 'leaf, dim.' \\
\hline g[a]t 'hole' & $\mathrm{g}[\mathrm{a}:] \mathrm{ten}$ & g[a:]tje 'hole, dim.' \\
\hline st[a]d 'city' & st[e:]den & st[e:]delijk 'urban' \\
\hline
\end{tabular}

The claim that we compute the allomorph by subtraction of the plural suffix is supported in particular by the last example in which the vowel not only lengthens but also changes its quality; the [e:] is also the stem vowel in stedelijk. 
The same determining role of the plural noun in stem allomorphy can be observed in the stem allomorphy in Frisian caused by the historical process of breaking discussed above. Tiersma (1983:65) lists a number of nouns that exhibit breaking in inflection and word formation. Based on this list we can make the generalization that the allomorph of the stem with the broken diphthong can (but need not) occur in a morphologically complex word if it occurs in the plural form. The only exceptions are the verb bworkje 'to farm' where the form of the plural for boer 'farmer' is claimed to only occur with the non-broken diphthong, and the word noas 'nose' where the plural noun is probably less frequent than the diminutive form that does have the 'broken' allomorph: nwaske. ${ }^{11}$

A final case of a particular morphological form fulfilling the role of being an allomorph of a related word that I would like to mention here comes from the Low-German dialect of Groningen. As pointed out by Hoekstra (1995:500ff), the diminutive form of a noun has to be used in the first position in compounds, without that noun having a diminutive interpretation: ${ }^{12}$

(32) bladje-mous lit. 'leaf vegetable, kale'

laandje-bloum lit. 'land flower, daisy'

neuske-bril lit. 'nose glasses'

goudje-bloem lit. 'gold flower'

anijske-brij 'aniseed porridge'

In short, the diminutive form has developed here into the allomorph to be used in the non-head position of compounds. Thus, this allomorph once more can be defined as being formally identical to a paradigmatically related word.

\subsection{Paradigmatic allomorphy and morphological change}

Our picture of the role of allomorphy is not complete if we consider it as just a "marginal synchronic junkpile" (Maiden 1992:285). Above, we already saw that, like paradigmatic word formation patterns, allomorphy patterns tell us something about the ways in which complex words that share certain morphemes are related: not only in terms of base word - derived words, but along other lines as well.

Interestingly, Maiden has argued that irregular allomorphy "is not merely the residual product of failure to analyze alternation into underlying invariance, but an autonomous principle rooted, like 'one meaning - one form', in the nature of the relationship between signans and signatum" (Maiden 1992:290). Maiden observed that leveling of allomorphy in the Italian conjugation system differentiates between conjugations: it is only in the first conjugation (which is the default one: Dressler \& Thornton 1991) that all verbs are leveled as far as the segmental alternations in the present tense stem allomorphs are concerned. In the other 
conjugations it is kept. In the non-default conjugations allomorphy was even reintroduced, e.g. in the verb fuggire 'to flee'. According to Maiden, the stem originally always ended in /ddž/, but /gg/ has been introduced into the $1 \mathrm{SG}$ and 3PL present Indicative and the 1, 2, 3SG and 3PL subjunctive:

(33) IND: fuggo fuggi fugge fuggiamo fuggite fuggono

SUB: fugga fugga fugga fuggiamo fuggiate fuggano

$$
(g g=[\mathrm{dd} z \check{ }] \text { before } e, i)
$$

So the particular distribution of the allomorphs over particular morpho-syntactic categories in the conjugation of verbs in -ire was also projected to this verb. There is one allomorph, /fugg/ for the $1 \mathrm{Sg}$ and 3PL Indicative, and the 1, 2, 3SG and 3PL subjunctive, and another allomorph, /fuddžl for the other forms of the present indicative and subjunctive.

This reintroduction of allomorphy reflects a general paradigm structure condition for Italian verbs observed by, among others, Matthews (1981), Vincent (1988), and Dressler \& Thornton (1991). They point out that all Italian verbs have two allomorphs to be used in present tenses: the root (without the thematic vowel) must be used to form the singular and the 3rd person plural forms of the present indicative and subjunctive, and the singular imperative. This allomorph has lexical stress on a root vowel. The allomorph with the thematic vowel of the relevant conjugational class is used for the other inflectional forms. In this allomorph, lexical stress is on the thematic vowel. Both allomorphs play a role in derivation and compounding.

This role of paradigm structure conditions implies that the 'paradigm' in its more restricted meaning, that of inflectional paradigm, has autonomous existence in morphology, and is not just an epiphenomenon, an effect of the way in which the morphosyntactic properties of words are expressed phonologically. Other arguments for the existence of paradigms in this sense are provided in Zwicky (1985), Carstairs (1987), and Wurzel (1989). For instance, regularities in syncretism patterns can be expressed by 'rules of referral' that predicts certain forms in a paradigm on the basis of other forms in that paradigm (Zwicky 1985). ${ }^{13}$

As far as the role of the paradigm in allomorphy is concerned, Dressler \& Thornton (1981) observed that the distributional pattern of the allomorphs of Italian verbs also determines the suppletion pattern for suppletive verbs like verb andare 'to go': ${ }^{14}$ 
(34) The template for udire, dovere, uscire, -ire inchoatives, suonare and andare:

\begin{tabular}{|ccll|}
\hline Indic. & Subj. & Indic. & Subj. \\
\hline 1 & 1 & vado & vada \\
2 & 2 & vai & vada \\
3 & 3 & va & vada \\
\hline 4 & 4 & andiamo & andiamo \\
5 & 5 & andate & andiate \\
\hline 6 & 6 & vanno & vadano \\
\hline
\end{tabular}

The crucial point is that, apart from the suppletive verb andare, five diverse alternations converge at the positions mentioned in the verb paradigm:

(35) example

udi-re 'to hear' dove-re 'to have to' usci-re 'to exit' fini-re 'to finish' sona-re 'to sound' allomorph for $\mathrm{Sg}$ and $3 \mathrm{Pl}$

odo-

dev-

esc-

finisc-

suon-

Therefore, one has to conclude that paradigmatic patterns of allomorphic or suppletive alternations are not just junk, the synchronic residue of historical processes, but have their own regularity. That is, we see again that there is paradigmatically determined allomorphy.

\section{Conclusions}

The research strategy advocated in this paper is that, if we want to find out whether morphology is different from syntax and phonology, and forms a module of its own, we should look for phenomena in which morphology is different. After a survey of the theoretical issues and relevant phenomena in section 1, I argued in section 2 that allomorphy is one of the typical instantiations of the autonomy of morphology, and does not lend itself to reduction to phonology. In section 3 , it was shown that allomorphy is interwoven with another characteristic feature of autonomous morphology, the role of paradigmatic relations between words. These paradigmatic relations appeared to play an important role in formulating regularities in allomorphy patterns. The autonomy of morphology is thus well supported by the facts of language. 


\section{Address of the author}

Geert Booij

Holland Institute of Generative Linguistics / Vakgroep Taalkunde, Vrije Universiteit

De Boelelaan 1105

NL-1081 HV Amsterdam

e-mail: booij@let.vu.nl

\section{Notes}

I This paper is based on lectures given at the University of Ferrara, Italy, May 1996. I would like to thank my colleagues Wolfgang Dressler, Martin Haspelmath, Franz Rainer, Sergio Scalise, Anna Thornton, Nigel Vincent, and the anonymous referees for their comments on a previous draft of this paper. The responsibility for the content of this paper is of course only mine.

2 For a discussion and defense of the principle of Lexical Integrity, see Bresnan \& Mchombo (1995).

3 These proposals have been criticized by Spencer (1995) as far as noun-incorporation is concerned.

4 Note also in this connection that Bybee \& Newman (1995) take the radical position that it is only due to historical causes that morphology resembles syntax, and that non-concatenative morphology is as easy as concatenative morphology for making complex words.

5 Cumulative exponence (Matthews 1974:147) is the phenomenon that more than one morphosyntactic category is expressed by one formative. This is called 'multiple exponence' by Spencer (1991:51). For instance, many Indo-European languages express case and number simultaneously by means of one ending. Extended exponence is the inverse phenomenon that one morphosyntactic category is expressed by more than one formative. For instance, in the English Past Tense form told the Past Tense is expressed by the particular vowel /o/ and the suffix $-d$. Cf. also Peterson (1993).

6 Scalise (1995) points out that in Italian we also need two stem allomorphs for verbs used in deverbal word formation. Compare, for instance, persuaditrice (with the stem persuad of the infinitive) with persuasore (with the stem persuas of the past participle persuaso), and correggibile (infinitive corregg-ere) with correttore (past participle corrett-o). However, the two stem allomorphs used in inflection are not enough to account for all allomorphy patterns in deverbal derivation, witness deverbal nouns like tensione (with the inflectional stems as in tendere - tesi-teso), as pointed out in Thornton 1990-1991.

7 See Corbett \& Fraser (1993) for extensive use of the idea of default allomorph selection.

8 Rainer (1993a) argued that there are also head operations in derivational morphology. The point is, however, that one has to specify which derivational processes are head operations, and which are not. That is, there is no general principle that predicts this. Therefore, I prefer a direct statement of the patterns involved in paradigmatic terms.

9 Exceptions with idiosyncratic allomorphs are: brillamment 'brilliantly', savamment 'learnedly', éloquemment 'eloquently', and apparemment 'apparently'.

10 I do not give an example here for the verb doen 'to do', with the deverbal noun daad 'deed'. We do have the noun dader 'wrong-doer', but this noun is to be seen as derived directly from the noun deed given the fact that it does not mean 'doer', for which Dutch has the word doener.

11 Tiersma (1985:23) states this regularity as follows: "if the plural of a noun is subject to breaking, the corresponding diminutive will be also."

12 The same allomorphic role for the diminutive noun is found in Frisian (Sybren Dyk, pers. comm.)

13 More arguments for the paradigm are given in Börjars et al. (1997).

14 The same observation is made in Aski (1995). 


\section{References}

Ackema, Peter. 1995. Syntax below Zero. Utrecht: LEd/OTS.

Anderson, Stephen R. 1992. A-morphous Morphology. Cambridge: Cambridge University Press.

Aronoff, Mark. 1976. Word Formation in Generative Grammar. Cambridge, MA: MIT Press.

Aronoff, Mark. 1994. Morphology by Itself. Cambridge, MA: MIT Press.

Aski, Jean M. 1995. "Verbal Suppletion: An Analysis of Italian, French, and Spanish to go." Linguistics 33, 403-432.

Baker, Mark. 1988. Incorporation. A Theory of Grammatical Function Changing. Chicago: Chicago University Press.

Becker, Thomas. 1990. Analogie und morphologische Theorie. München: Fink Verlag.

Becker, Thomas. 1993. "Back-formation, Cross-formation, and 'Bracketing Paradoxes'." In: Booij \& van Marle (eds.), 1-26.

Bloomfield, Leonard. 1933. Language. London: Allen \& Unwin.

Booij, Geert. 1987. "Lexical Phonology and the Organization of the Morphological Component." In: Edmund Gussmann (ed.), Rules and the Lexicon. Lublin: Catholic University of Lublin, 43-66.

Booij, Geert. 1989. "Complex Verbs and the Theory of Level Ordering." In: Geert Booij \& Jaap van Marle (eds.), Yearbook of Morphology 1989. Dordrecht: Foris. 21-30.

Booij, Geert. 1992. "Morphology, Semantics, and Argument Structure." In: Iggy Roca (ed.), Thematic Structure, its Role in Grammar. Berlin: Foris, 47-63.

Booij, Geert. 1994. "Lexical Phonology, a Review." Lingua e Stile 24, 525-555.

Booij, Geert. 1995. The Phonology of Dutch. Oxford: Clarendon Press.

Booij, Geert. 1997. “Autonomous Morphology and Paradigmatic Relations." In: Booij \& van Marle (eds.). 1997, 35-54.

Booij, Geert \& Jaap van Marle (eds.). 1993. Yearbook of Morphology 1993. Dordrecht: Kluwer

Booij, Geert \& Jaap van Marle (eds.). 1997. Yearbook of Morphology 1996. Dordrecht: Kluwer.

Borer, Hagit. 1988. "On the Morphological Parallellism between Compounds and Constructs." In: Geert Booij \& Jaap van Marle (eds.), Yearbook of Morphology 1988. Dordrecht: Foris, 45-66.

Borer, Hagit. 1991. "The Causative-Inchoative Alternation: A Case Study in Parallel Morphology." The Linguistic Review 8, 119-158.

Börjars, Kersti, Carol Chapman \& Nigel Vincent. 1997. "Paradigms, Periphrases and Pronominal Inflection.” In: Booij \& van Marle (eds.). 1997, 155-180.

Bresnan, Joan \& Sam Mchombo. 1995. "The Lexical Integrity Principle; Evidence from Bantu." Natural Language and Linguistic Theory 13, 181-254.

Bybee, Joan L. \& Jean E. Newman. 1995. “Are Stem Changes as Natural as Affixes?" Linguistics 33, 633-655.

Carstairs, Andrew. 1987. Allomorphy in Inflexion. London: Croom Helm.

Chomsky, Noam. 1970. "Remarks on Nominalization." In: Roderick A. Jacobs \& Peter S. Rosenbaum (eds.), Readings in English Transformational Grammar. Waltham MA: Ginn \& Company, 184-221.

Corbett, Greville C. \& Norman M. Fraser. 1993. "Network Morphology: A DATR Account of Russian Nominal Inflection." Journal of Linguistics 29, 13-142.

Di Sciullo, Anna-Maria \& Edwin Williams. 1987. On the Definition of Word. Cambridge, MA: MIT Press.

Dressler, Wolfgang U. 1985. Morphonology. The Dynamics of Derivation. Ann Arbor: Karoma Press.

Dressler, Wolfgang U. \& Lavinia Merlini Barbaresi. 1991. "Interradical Interfixes: Contact and Contrast." In: Vladimir Ivir \& Damir Kalogjera (eds.), Languages in Contact and Contrast. Essays in Contact Linguistics. Berlin: Mouton de Gruyter, 133-145. 
Dressler, Wolfgang U. \& Anna M. Thornton. 1991. "Doppie basi e binarismo nella morfologia italiana." Rivista di Linguistica 3, 3-22.

Duncan, Edwin, Donka Farkas \& Philip Spaelti (eds.). 1993. Proceedings of the West Coast Conference on Formal Linguistics 12. Stanford: CSLI.

Goldsmith, John. 1995. "Introduction." In: id. (ed.), 1-15.

Goldsmith, John (ed.). 1995. The Handbook of Phonological Theory. Oxford - Cambridge, MA: Blackwell.

Haas, Wim de \& Mieke Trommelen. 1993. Morfologisch Handboek van het Nederlands. 's Gravenhage: SDU Uitgeverij.

Hale, Ken \& Samuel J. Keyser. 1993, "On Argument Structure and the Lexical Expression of Syntactic Relations." In: Hale \& Keyser (eds.), 53-110.

Hale, Ken \& Samuel J. Keyser (eds.). 1993. The View from Building 20. Cambridge, MA: MIT Press.

Halle, Morris. 1973. "Prolegomena to a Theory of Word Formation." Linguistic Inquiry 4, 3-16.

Halle, Morris \& Alec Marantz. 1993. "Distributed Morphology and the Pieces of Inflection." In: Hale \& Keyser (eds.), 111-176.

Harris, John. 1994. English Sound Structure. Oxford: Blackwell.

Harris, James. 1995. "Projection and Edge Marking in the Computation of Stress in Spanish." In: Goldsmith (ed.), 867-887.

Haspelmath, Martin. 1992. "Grammaticization Theory and Heads in Morphology." In: Mark Aronoff (ed.), Morphology Now. Albany: SUNY Press, 69-82.

Hoekstra, Eric. 1995. "Iets over eerste leden van samenstellingen." Leuvense Bijdragen 84, 491-504.

Hoekstra, Teun et al. 1987. "Complexe verba." GLOT 10,61-78.

Hopper, Paul \& Elizabeth Traugott. 1993. Grammaticalization. Cambridge: Cambridge University Press.

Inkelas, Sharon. 1993. "Nimboran Position Class Morphology." Natural Language and Linguistic Theory 11, 559-624.

Jackendoff. Ray. 1975. "Morphological and Semantic Regularities in the Lexicon." Language 51, 639-671.

Lieber, Rochelle. 1980. On the Organization of the Lexicon. Diss., MIT.

Lieber, Rochelle. 1992. Deconstructing Morphology. Chicago: University of Chicago Press.

Loey, A. van. ${ }^{7} 1964$. Schönfelds historische grammatica van het Nederlands. Zutphen: Thieme.

Maiden, Martin. 1992. "Irregularity as a Determinant of Morphological Change." Journal of Linguistics 28, 285-312.

Marle, Jaap van. 1985. On the Paradigmatic Dimension of Morphological Creativity. Dordrecht: Foris.

Matthews, Peter H. 1972. Inflectional Morphology. Cambridge: Cambridge University Press.

Matthews, Peter H. 1974. Morphology. Cambridge: Cambridge University Press.

Matthews, Peter H. 1981. "Present Stem Alternation in Italian." In: Logos Semantikos. Festschrift für E. Coseriu. Berlin: de Gruyter, 57-65.

McCarthy, John \& Alan Prince. 1993. "Generalized Alignment." In: Booij \& van Marle (eds.), 79-153.

Mohanan, K.P. 1995. "The Organization of the Grammar," In: Goldsmith (ed.), 24-69.

Noyer, Rolph. 1992. Features, Positions, and Affixes in Autonomous Morphological Structure. Ph.D. Diss., MIT.

Noyer, Rolph. 1993. "Mobile Affixes in Huave: Optimality and Morphological Wellformedness." In: Duncan et al. (eds.), 67-82.

Peterson, David A. 1993. "Multiple Exponence and Morphosyntactic Redundancy." In: Duncan et al. (eds.), 83-100.

Pullum, Geoff K. \& Arnold Zwicky. 1988. "The Syntax-Phonology Interface.” In: Frederick Newmeyer (ed.), Linguistics; the Cambridge Survey. Vol 1. Cambridge: Cambridge University Press, 255-280. 
Rainer, Franz. 1993a. "Head-operations in Spanish Morphology." In: Geert Booij \& Jaap van Marle (eds.), Yearbook of Morphology 1992. Dordrecht: Kluwer, 113-128.

Rainer, Franz. 1993b. Spanische Wortbildung. Tübingen: Niemeyer.

Rubach, Jerzy. 1984. Cyclic and Lexical Phonology. Dordrecht: Foris.

Scalise, Sergio. 1995. "Preliminari per lo studio di un affisso: -tore o -ore?" In: Paola Benincá, Guiglielmo Cinque, Tullio De Mauro \& Nigel Vincent (eds.), Italiano e dialetti nel tempo. Saggi di grammatica per Giulio C. Lepschy. Roma: Bulzoni, 291-307.

Selkirk, Elizabeth O. 1982. The Syntax of Words. Cambridge, MA: MIT Press.

Speas, Margaret. 1991. "Functional Heads and the Inflectional Morphemes." The Linguistic Review 8, 389-416.

Spencer, Andrew. 1988. "Arguments for Morpholexical Rules." Journal of Linguistics 24, 1-29.

Spencer, Andrew. 1991. Morphological Theory. Oxford - Cambridge, MA: Blackwell.

Spencer, Andrew. 1992. "Nominal Inflection and the Nature of Functional Categories." Journal of Linguistics 28. 313-341.

Spencer, Andrew. 1993. "Review of Lieber (1992)." Language 69, 580-587.

Spencer, Andrew. 1995. "Incorporation in Chukchi." Language 71, 439-489.

Steele, Susan. 1995. "Towards a Theory of Morphological Information." Language 71, 260-309.

Stump, Gregory. 1995. "The Uniformity of Head Marking in Inflectional Morphology." In: Geert Booij \& Jaap van Marle (eds.), Yearbook of Morphology 1994. Dordrecht: Kluwer, 245-296.

Szymanek, Bogdan. 1985. "On Intermorphic Extensions in English and Polish." In: Edmund Gussmann (ed.), Phono-morphology. Lublin: Catholic University of Lublin, 177-192.

Thornton, Anna Maria. 1990-1991. "Su i deverbali italiani in -mento e -zione, I, II." Archivio Glottologio Italiano 75, 169-207; 76, 79-102.

Tiersma, Peter. 1983. "The Nature of Phonological Representation: Evidence from Breaking in Frisian." Journal of Linguistics 19, 59-78.

Tiersma, Pieter M. 1985. Frisian Reference Grammar. Dordrecht: Foris.

Toman, Jindřich. 1983. Wortsyntax. Niemeyer: Tübingen.

Vennemann, Theo. 1972. "Rule Inversion." Lingua 29, 209-242.

Vincent, Nigel. 1988. "Italian." In: Martin Harris \& Nigel Vincent (eds.), The Romance Languages. London/Sidney: Croom Helm, 279-313.

Vogel, Irene. 1993. "Verbs in Italian Morphology." In: Booij \& van Marle (eds.), 219-254.

Williams, Edwin. 1981. "On the Notions 'Lexically Related' and 'Head of a Word'." Linguistic Inquiry $12,245-274$.

Wurzel, Wolfgang U. 1989. Inflectional Morphology and Naturalness. Dordrecht: Kluwer.

Zonneveld, Wim. 1978. A Formal Theory of Exceptions in Generative Phonology. Dordrecht: Foris.

Zwicky, Arnold. 1985. "How to Describe Inflection." Proceedings of the Berkeley Linguistic Society $11,372-386$. 